\title{
Occurrences of antibodies against Toxoplasma gondii, Neospora spp., and Sarcocystis neurona in horses and dogs in the municipality of Pauliceia, São Paulo, Brazil
}

\section{Ocorrências de anticorpos anti-Toxoplasma gondii, Neospora spp.e Sarcocystis neurona em equinos e cães do município de Pauliceia, São Paulo, Brasil}

\author{
Solange OLIVEIRA ${ }^{1}$; Natalia Quadros Bressa SILVA ${ }^{1}$; Iara SILVEIRA ${ }^{1}$; Marcelo Bahia LABRUNA ${ }^{1}$; \\ Solange Maria GENNARI ${ }^{1}$; Hilda Fátima Jesus PENA ${ }^{1}$ \\ ${ }^{1}$ Universidade de São Paulo, Faculdade de Medicina Veterinária e Zootecnia, \\ Departamento de Medicina Veterinária Preventiva e Saúde Animal, São Paulo - SP, Brazil
}

\begin{abstract}
Serum samples from 116 horses and 47 dogs from the municipality of Paulicéia, in the state of São Paulo, Brazil, were examined for anti-Toxoplasma gondii, -Neospora spp. and -Sarcocystis neurona antibodies by means of the indirect fluorescent antibody test (IFAT). The results showed that only one horse was seropositive for T. gondii (0.9\%) and anti-Neospora spp. antibodies were detected in three out of the 116 horses tested (2.6\%). However, 27 horses showed antibodies against S. neurona (23.8\%). Amongst the serum samples from the dogs, 10 out of the 47 dogs showed antibodies against $T$. gondii (21.3\%) and three dogs showed antibodies against Neospora caninum (6.4\%). This study reports that in the municipality of Paulicéia dogs in both the rural and the urban area were exposed to T. gondii and $N$. caninum, while horses in the rural area were exposed to all three protozoa studied, with high occurrence of anti-S. neurona antibodies.
\end{abstract}

Keywords: Toxoplasmosis. Neosporosis. Equine protozoal myeloencephalitis. IFAT.

\section{Resumo}

Amostras de soro de 116 equinos e 47 cães provenientes do município de Paulicéia, São Paulo, foram testadas para detecção de anticorpos anti-Toxoplasma gondii, -Neospora spp. e -Sarcocystis neurona por meio da reação de imunofluorescência indireta (RIFI). Apenas um equino, entre 116 equinos testados, teve diagnóstico soropositivo para T. gondii $(0,9 \%)$, e três deles $(2,6 \%)$ apresentaram anticorpos anti-Neospora spp. Entretanto, 27 equinos apresentaram anticorpos anti-S. neurona (23,8\%). Nas amostras de cães, dez dos 47 animais apresentaram anticorpos anti-T. gondii $(21,3 \%)$ e três tiveram diagnóstico soropositivo para Neospora caninum $(6,4 \%)$. Este estudo relata que no município de Paulicéia os cães das áreas urbana e rural foram expostos a T. gondii e N. caninum, enquanto os equinos da área rural foram expostos aos três protozoários estudados, com alta ocorrência de anticorpos anti- S. neurona.

Palavras-chave: Toxoplasmose. Neosporose. Mieloencefalite protozoária equina. RIFI.

Correspondence to:

Hilda Fátima Jesus Pena

Universidade de São Paulo, Faculdade de Medicina Veterinária e Zootecnia, Departamento de Medicina Veterinária Preventiva e Saúde Animal

Av. Prof. Dr. Orlando Marques de Paiva, 87

CEP 05508-270, São Paulo, SP, Brazil

E-mail: hfpena@usp.br

Received: 09/12/2016

Approved: 27/07/2017
The protozoa Toxoplasma gondii, Neospora spp., and Sarcocystis neurona belong to the phylum Apicomplexa and have been correlated with animal diseases (DUBEY, 2010; DUBEY et al., 2016; DUBEY et al., 2017), furthermore T. gondii is also globally correlated with human disease (DUBEY, 2010).

The zoonotic agent $T$. gondii is the parasite of this phylum that has been studied most and it can infect virtually all warm-blooded animals (DUBEY, 2010). Ingestion of raw or undercooked meat, including horsemeat, is a 
mode of transmission to carnivores and humans. Brazil is an important exporter of horsemeat (BRASIL, 2016). Herbivores can become infected through ingestion of sporulated oocysts in the environment. Felids can excrete the oocysts in their feces and are the only definitive hosts (DUBEY, 2010).

The definitive hosts of Neospora caninum are domestic dogs and other species of canids (MCALLISTER et al., 1998; GONDIM et al., 2004; KING et al., 2010; DUBEY et al., 2011). Dogs can also act as intermediate hosts and may be severely affected by N. caninum (DUBEY, 2013). The presence of antibodies against $N$. caninum in dogs has been reported worldwide and sometimes dogs have been implicated as a potential risk factor for infection in livestock (FERROGLIO et al., 2007; PAULAN et al., 2013; ABREU et al., 2014). Furthermore, dogs are considered to be sentinels for T. gondii infection, because of their feeding behavior.

Equine protozoal myeloencephalitis (EPM) is a neurological disorder in horses that is most often caused by $S$. neurona. In South America the opossum Didelphis albiventris is known as a definitive host and horses participate as an accidental host of S. neurona (DUBEY et al., 2015). Another pathogen associated with EPM is Neospora hughesi, however, information about the life cycle of this parasite is very limited. Moreover, the way in which N. caninum participates in neurological diseases or reproductive failures in horses is unclear (VILLALOBOS et al., 2006; FINNO et al., 2010; ANTONELLO et al., 2012).

In Brazil different rates of occurrence of antibodies against T. gondii, Neospora spp., and S. neurona among horses, and antibodies against $T$. gondii and $N$. caninum in dogs have been reported (LOCATELLI-DITTRICH et al., 2006; PAULAN et al., 2013; GENNARI et al., 2016; RIBEIRO et al., 2016).

The purpose of this survey was to report occurrences of antibodies against T. gondii, Neospora spp., and $S$. neurona in horses and dogs in the urban and rural areas of the municipality of Paulicéia, in the western region of the state of São Paulo, Brazil. For this purpose, horses and dogs of both genders and different ages on 10 farms (locations A-J) and in the urban area of the municipality were sampled. The blood samples were collected from 2008 to 2009 , during a survey on rickettsial infection in humans and animals, and more details about the study area and sample collection were described by Silveira et al. (2015). All animals were handled in accordance with approved protocols from the Ethics Committee for Animal Use of the School of Veterinary Medicine, University of São Paulo.

Serum samples from 116 horses and 47 dogs were tested by means of the indirect fluorescent antibody test (IFAT) using culture-derived tachyzoites of $T$. gondii (RH strain) or N. caninum (NC-1 strain) and merozoites of S. neurona (SN 138 strain) as antigens, in accordance with protocols described by Camargo (1974), Dubey et al. (1988), and Duarte et al. (2003), respectively. The cutoff dilutions were 1:16 (dogs) and 1:64 (horses) for T. gondii, 1:50 for $N$. caninum (dogs and horses) and 1:80 for S. neurona (horses), as specified in previous publications. Anti-horse or anti-dog IgG conjugates labelled with fluorescein isothiocyanate (FITC) (Sigma-Aldrich', St. Louis, MO, USA) were used as a secondary antibody. Positive and negative controls were used in all reactions. We assumed that seropositive horses for the N. caninum antigen were seropositive for Neospora spp., due to the cross-reactivity between $N$. caninum and $N$. hughesi that has been observed in serological tests (GONDIM et al., 2009).

Only one horse showed antibodies against T. gondii (0.9\%) and the titer was 64. Anti-Neospora spp. antibodies were found in three out of the 116 horses (2.6\%), with titers of 50 (two horses) and 400 (one horse). However, 27 horses were seropositive for S. neurona (23.8\%) and between them 10 had titers $=80$, seven $=160$, three $=320$, six $=$ 640 , and one $=1280$. Among the total of 31 seropositive horses, none of them had antibodies against more than one of the pathogens under investigation. Amongst the 47 dogs that were tested, 10 were seropositive for T. gondii (21.3\%), with titers of 32 (two dogs), 64 (four dogs), 128 (three dogs), and 1024 (one dog). Antibodies against $N$. caninum were detected in three dogs $(6.4 \%)$, with titers of 50,100 , and 200. One out of the total 13 seropositive dogs showed antibodies against both $T$. gondii and $N$. caninum. The distribution of the seropositive animals according to location is summarized in Table 1.

In the present study we found very low occurrence of anti- $T$. gondii antibodies in the horses, however, around $20 \%$ of the dogs examined were seropositive for T. gondii, which demonstrates that the parasite is circulating in the region studied. The only seropositive horse was on a farm where dogs had high seropositivity (28.8\%) (Table 1 ). Antibodies against $T$. gondii have also been detected in horses in different municipalities in Brazil, using IFAT. In Botucatu (São Paulo) 5.9\% (42/714) of the horses showed these antibodies (COIRO et al., 2012). Finger et al. (2013) 
Table 1 - Occurrences of antibodies against Toxoplasma gondii, Neospora spp. and Sarcocystis neurona in horses and dogs on different farms (A to J) and in the urban area of the municipality of Paulicéia, state of São Paulo, Brazil - 2016

\begin{tabular}{|c|c|c|c|c|c|c|}
\hline \multirow{3}{*}{ Location } & \multicolumn{2}{|c|}{ T. gondii } & \multicolumn{2}{|c|}{ Neospora spp. } & \multicolumn{2}{|c|}{ S. neurona } \\
\hline & \multicolumn{2}{|c|}{ N. seropositive /N. tested (\%) } & \multicolumn{2}{|c|}{ N. seropositive /N. tested (\%) } & \multicolumn{2}{|c|}{ N. seropositive /N. tested (\%) } \\
\hline & Horses & Dogs & Horses & Dogs & Horses & Dogs \\
\hline Urban & $0 / 11(0)$ & $2 / 10(20)$ & $1 / 11(9)$ & $1 / 10(10)$ & $3 / 11(27.3)$ & ND \\
\hline$A$ & $0 / 14(0)$ & $1 / 6(17)$ & $0 / 14(0)$ & $0 / 6(0)$ & $6 / 14(43)$ & ND \\
\hline $\mathrm{B}$ & $1 / 48(2)$ & 4/14 (28.6) & $2 / 48(4.2)$ & $0 / 14(0)$ & $9 / 48(18.8)$ & ND \\
\hline $\mathrm{C}$ & $0 / 3(0)$ & $1 / 4(25)$ & $0 / 3(0)$ & $0 / 4(0)$ & $1 / 3(33.3)$ & ND \\
\hline $\mathrm{D}$ & $0 / 4(0)$ & $0 / 2(0)$ & $0 / 4(0)$ & $0 / 2(0)$ & $1 / 4(25)$ & ND \\
\hline $\mathrm{E}$ & $0 / 5(0)$ & $0 / 1(0)$ & $0 / 5(0)$ & $0 / 1(0)$ & $2 / 5(40)$ & ND \\
\hline $\mathrm{F}$ & $0 / 2(0)$ & $1 / 1(100)$ & $0 / 2(0)$ & $0 / 1(0)$ & $2 / 2(100)$ & ND \\
\hline G & $0 / 15(0)$ & $0 / 2(0)$ & $0 / 15(0)$ & $1 / 2(50)$ & $1 / 15(6.7)$ & ND \\
\hline $\mathrm{H}$ & $0 / 7(0)$ & No sample & $0 / 7(0)$ & No sample & $0 / 7(0)$ & ND \\
\hline 1 & $0 / 2(0)$ & $0 / 3(0)$ & $0 / 2(0)$ & $1 / 3(33.3)$ & $0 / 2(0)$ & ND \\
\hline J & $0 / 5(0)$ & $1 / 4(25)$ & $0 / 5(0)$ & $0 / 4(0)$ & $2 / 5(40)$ & ND \\
\hline Total & $1 / 116(0.9)$ & $10 / 47(21.3)$ & $3 / 116(2.6)$ & $3 / 47(6.4)$ & $27 / 116(23.8)$ & ND \\
\hline
\end{tabular}

ND: not done

found in Curitiba (Paraná) that $17 \%$ of the carthorses were seropositive and Gennari et al. (2015) reported that 22 out of 57 horses in Petrolina (Pernambuco) were seropositive (38.5\%).

The rates of occurrence of anti-Neospora spp. and anti-S. neurona antibodies in horses were similar to what has been found in other studies in Brazil. Ribeiro et al. (2016) found that 23.9\% (107/506) and 26\% (117/506) of the horses were seropositive for Neospora spp. and S. neurona, respectively in Minas Gerais, by means of IFAT. In addition, serum samples from 961 horses in different states in Brazil have been tested (ELISA) and the seroprevalence was 2.5\% (24/961) for Neospora spp. and $69.6 \%$ (669/961) for S. neurona (HOANE et al., 2006). Occurrence of antibodies against Neospora spp. and $S$. neurona in the horses from the present report indicates exposure to a source of infection, such as environmental contamination with oocysts excreted by the dogs on the farms or sporocysts excreted by opossums, respectively. During sample collection, the opossum $D$. albiventris was captured in the study area (SILVEIRA et al., 2015).

In our study the rates of occurrence of anti-T. gondii antibodies (21.3\%) and $N$. caninum antibodies (6.4\%) in dogs were also similar to previous findings, also from IFAT.
In Brotas (São Paulo) Langoni et al. (2013) tested 342 dogs and $26.9 \%$ and $4.9 \%$ were seropositive for T. gondii and $N$. caninum, respectively. Paulan et al. (2013) examined serum samples from rural dogs in Ilha Solteira (São Paulo), and found occurrences of $47.3 \%$ for T. gondii and $6.4 \%$ for $N$. caninum. However, in the study by Lopes et al. (2015), stray dogs in Natal (Rio Grande do Norte) presented lower occurrences: $12.7 \%$ and $2.9 \%$ for T. gondii and N. caninum, respectively. Dogs are carnivores, but they can eat a large variety of food, including garbage, which presumably allows them to come into closer contact with different sources of infection.

In conclusion, this study reported that horses and dogs in the municipality of Paulicéia have been exposed to the protozoa T. gondii, Neospora spp. or S. neurona.

\section{Acknowledgements}

To the Research Support Foundation of the State of São Paulo (Fundação de Amparo à Pesquisa do Estado de São Paulo, FAPESP) (Grant n. 2007/597069) for financial support. S.M. Gennari and M.B. Labruna hold fellowships from the National Council for Scientific and Technological Development (Conselho Nacional de Desenvolvimento Científico e Tecnológico, CNPq). 


\section{References}

ABREU, R. A.; WEISS, R. R.; THOMAZ-SOCCOL, V.; LOCATELLI-DITTRICH, R.; LASKOSKI, L. M.; BERTOL, M. A.; KOCH, M. O.; ALBAN, S. M.; GREEN, K. T. Association of antibodies against Neospora caninum in mares with reproductive problems and presence of seropositive dogs as a risk factor. Veterinary Parasitology, v. 202, n. 3-4, p. 128-131, 2014. doi: 10.1016/j. vetpar.2014.03.022.

ANTONELlO, A. M.; PIVOTO, F. L.; CAMILLO, G.; BRAUNIG, P.; SANGIONI, L. A.; POMPERMAYER, E.; VOGEL, F. S. The importance of vertical transmission of Neospora sp. in naturally infected horses. Veterinary Parasitology, v. 187, n. 3-4, p. 367-370, 2012. doi: 10.1016/j. vetpar.2012.02.005.

BRASIL. Ministério da Agricultura, Pecuária e Abastecimento. Equinos. Brasília, 2016. Available from: <http://bit.ly/2hnBcnX>. Viewed: 15 Aug. 2016.

CAMARGO, M. E. Introdução as técnicas de imunofluorescência. Revista Brasileira Patologia Clínica, v. 10, n. 3, p. 87-107, 1974.

COIRO, C. J.; LANGONI, H.; DA SILVA, R. C. Epidemiological aspects in the Leptospira spp. and Toxoplasma gondii infection in horses from Botucatu, São Paulo, Brazil. Journal of Equine Veterinary Science, v. 32, n. 10, p. 620-623, 2012. doi: 10.1016/j.jevs.2012.02.008.

DUARTE, P. C.; DAFT, B. M.; CONRAD, P. A.; PACKHAM, A. E.; GARDNER, I. A. Comparison of a serum indirect fluorescent antibody test with two Western blot tests for the diagnosis of equine protozoal myeloencephalitis. Journal of Veterinary Diagnostic Investigation, v. 15, n. 1, p. 8-13, 2003. doi: 10.1177/104063870301500103.

DUBEY, J. P. Neosporosis in dogs. CAB Reviews, v. 8, n. 55, p. 1-26, 2013. doi: 10.1079/PAVSNNR20138055.

DUBEY, J. P. Toxoplasmosis of Animals and Humans. 2. ed. Boca Raton: CRC Press, 2010.

DUBEY, J. P.; CALERO-BERNAL, R.; ROSENTHAL, B. M.; SPEER, C. A.; FAYER, R. Sarcocystosis of Animals and Humans. 2. ed. Boca Raton: CRC Press, 2016.
DUBEY, J. P.; CARPENTER, J. L.; SPEER, C. A.; TOPPER, M. J.; UGGLA, A. Newly recognized fatal protozoan disease of dogs. Journal American Veterinary Medicine Association, v. 192, n. 9, p. 1269-1285, 1988.

DUBEY, J. P.; HEMPHILL, A.; CALERO-BERNAL, R.; SCHARES, G. Neosporosis of Animals, Boca Raton: CRC Press, 2017. In press.

DUBEY, J. P.; HOWE, D. K.; FURR, M.; SAVILLE, W. J.; MARSH, A. E.; REED, S. M.; GRIGG, M. E. An update on Sarcocystis neurona infections in animals and equine protozoal myeloencephalitis (EPM). Veterinary Parasitology, v. 209, n. 1-2, p. 1-42, 2015. doi: 10.1016/j. vetpar.2015.01.026.

DUBEY, J. P.; JENKINS, M. C.; RAJENDRAN, C.; MISKA, K.; FERREIRA, L. R.; MARTINS, J.; KWOK, O. C. H.; CHOUDHARY, S. Gray wolf (Canis lupus) is a natural definitive host for Neospora caninum. Veterinary Parasitology, v. 181, n. 2-4, p. 382-387, 2011. doi: 10.1016/j. vetpar.2011.05.018.

FERROGLIO, E.; PASINO, M.; RONCO, F.; BENÀ, A.; TRISCIUOGLIO, A. Seroprevalence of antibodies to Neospora caninum in urban and rural dogs in north-west Italy. Zoonoses and Public Health, v. 54, n. 3-4, p. 135-139, 2007. doi: 10.1111/j.1863-2378.2007.01033.x.

FINGER, M. A.; VILLALOBOS, E. M. C.; LARA, M. C.; CUNHA, E. M. S.; BARROS FILHO I. R.; DECONTO, I.; DORNBUSCH, P. T.; ULLMANN, L. S.; BIONDO, A. W. Detection of anti-Toxoplasma gondii antibodies in carthorses in the metropolitan region of Curitiba, Paraná, Brazil. Revista Brasileira de Parasitologia Veterinária, v. 22, n. 1, p. 179-181, 2013. doi: 10.1590/ S1984-29612013005000001.

FINNO, C. J.; EATON, J. S.; ALEMAN, M.; HOLLINGSWORTH, S. R. Equine protozoal myeloencephalitis due to Neospora hughesi and equine motor neuron disease in a mule. Veterinary Ophthalmology, v. 13, n. 4, p. 259-265, 2010. doi: 10.1111/j.1463-5224.2010.00790.x. 
GENNARI, S. M.; ESMERINI, P. O.; LOPES, M. G.; SOARES, H. S.; VITALIANO, S. N.; CABRAL, A. D.; PENA, H. F. J.; HORTA, M. C.; CAVALCANTE, P. H.; FORTES, K. P.; VILLALOBOS, E. M. C. Occurrence of antibodies against Toxoplasma gondii and its isolation and genotyping in donkeys, mules, and horses in Brazil. Veterinary Parasitology, v. 209, n. 1-2, p. 129-132, 2015. doi: 10.1016/j.vetpar.2015.01.023.

GENNARI, S. M.; PENA, H. F. J.; LINDSAY, D. S.; LOPES, M. G.; SOARES, H. S.; CABRAL, A. D.; VITALIANO, S. N.; AMAKU, M. Prevalence of antibodies against Neospora spp. and Sarcocystis neurona in donkeys from northeastern Brazil. Revista Brasileira de Parasitologia Veterinária, v. 25, n. 1, p. 109-111, 2016. doi: 10.1590/ S1984-29612016003.

GONDIM, L. F. P.; LINDSAY, D. S.; MCALLISTER, M. M. Canine and bovine Neospora caninum control sera examined for cross-reactivity using Neospora caninum and Neospora hughesi indirect fluorescent antibody tests. The Journal of Parasitology, v. 95, n. 1, p. 86-88, 2009. doi: 10.1645/GE-1710.1.

GONDIM, L. F.; MCALLISTER, M. M.; PITT, W. C.; ZEMLICKA, D. E. Coyotes (Canis latrans) are definitive hosts of Neospora caninum. International Journal for Parasitology, v. 34, n. 2, p. 159-161, 2004. doi: 10.1016/j. ijpara.2004.01.001.

HOANE, J. S.; GENNARI, S. M.; DUBEY, J. P.; RIBEIRO, M. G.; BORGES, A. S.; YAI, L. E. O.; AGUIAR, D. M.; CAVAlCANTE, G. T.; BONESI, G. L.; HOWE, D. K. Prevalence of Sarcocystis neurona and Neospora spp. infection in horses from Brazil based on presence of serum antibodies to parasite surface antigen. Veterinary Parasitology, v. 136, n. 2, p. 155-159, 2006. doi: 10.1016/j. vetpar.2005.10.023.

KING, J. S.; ŠLAPETA, J.; JENKINS, D. J.; AL-QASSAB, S. E.; ELLIS, J. T.; WINDSOR, P. A. Australian dingoes are definitive hosts of Neospora caninum. International Journal for Parasitology, v. 40, n. 8, p. 945-950, 2010. doi: 10.1016/j.ijpara.2010.01.008.

LANGONI, H.; FORNAZARI, F.; SILVA, R. C.; MONTI, E. T.; VILLA, F. B. Prevalence of antibodies against
Toxoplasma gondii and Neospora caninum in dogs. Brazilian Journal of Microbiology, v. 44, n. 4, p. 13271330, 2013. doi: 10.1590/S1517-83822013000400043.

LOCATELLI-DITTRICH， R.; DITTRICH， J. R.; RICHARTZ, R. R. T. B.; GASINO JOINEAU, $M$. E.; ANTUNES, J.; PINCKNEY, R. D.; DECONTO, I.; HOFFMANN, D. C. S.; THOMAZ-SOCCOL, V. Investigation of Neospora sp. and Toxoplasma gondii antibodies in mares and in precolostral foals from Paraná State, Southern Brazil. Veterinary Parasitology, v. 135, n. 3-4, p. 215-221, 2006. doi: 10.1016/j.vetpar.2005.10.010.

LOPES, M. G.; HERNANDEZ, M.; LIMA, J. T. R.; GRISI FILHO, J. H. H.; GENNARI, S. M. Occurrence of antibodies anti-Toxoplasma gondii and anti-Neospora caninum in dogs from Natal, RN, Brazil. Brazilian Journal of Veterinary Research and Animal Science, v. 52, n. 2, p. 120, 2015. doi: 10.11606/issn.1678-4456.v52i2p120-124.

MCALLISTER, M. M.; DUBEY, J. P.; LINDSAY, D. S.; JOLLEY, W. R.; WILLS, R. A.; MCGUIRE, A. M. Dogs are definitive hosts of Neospora caninum. International Journal for Parasitology, v. 28, n. 9, p. 1473-1479, 1998. doi: 10.1016/S0020-7519(98)00138-6.

PAUlAN, S. D. C.; LINS, A. G. D. S.; TENÓRIO, M. D. S.; SILVA, D. T.; PENA, H. F. D. J.; MACHADO, R. Z.; GENNARI, S. M.; BUZETTI, W. A. S. Seroprevalence rates of antibodies against Leishmania infantum and other protozoan and rickettsial parasites in dogs. Brazilian Journal of Veterinary Parasitology, v. 22, n. 1, p. 162-166, 2013. doi: 10.1590/S1984-29612013000100031.

RIBEIRO, M. J. M.; ROSA, M. H. F.; BRUHN, F. R. P.; GARCIA, A. M.; ROCHA, C. M. B.; GUIMARÃES, A. M. Seroepidemiology of Sarcocystis neurona, Toxoplasma gondii and Neospora spp. among horses in the south of the state of Minas Gerais, Brazil. Brazilian Journal Veterinary Parasitology, v. 25, n. 2, p. 142-150, 2016. doi: $10.1590 /$ S1984-29612016029.

SILVEIRA, I.; MARTINS, T. F.; OLEGÁRIO, M. M.; PETERKA, C.; GUEDES, E.; FERREIRA, F.; LABRUNA, M. B. Rickettsial infection in animals, humans and ticks in Paulicéia, Brazil. Zoonoses and Public Health, v. 62, n. 7, p. 525-533, 2015. doi: 10.1111/zph.12180.

Braz. J. Vet. Res. Anim. Sci., São Paulo, v. 54, n. 3, p. 277-282, 2017 
VILLALOBOS, E. M. C.; UENO, T. E. H.; SOUZA, S. L. of serum antibodies against Neospora spp. and fetal loss P.; CUNHA, E. M. S.; LARA, M. C. C. S. H.; GENNARI, $\quad$ in equines. Veterinary Parasitology, v. 142, n. 3-4, p. 372S. M.; SOARES, R. M. Association between the presence $\quad$ 375, 2006. doi: 10.1016/j.vetpar.2006.07.016. 